J. Amer. Soc. Hort. ScI. 115(4):534-539. 1990.

\title{
Relationships Between the Yield and Vegetative Characteristics of Individual Shoots of 'Cabernet Sauvignon' Grapevines
}

\author{
P.A. Bowen' and W.M. Kliewer \\ Department of Viticulture and Enology, University of California, Davis, CA 95616 \\ Additional index words. plastochron index, Vitis vinifera, yield component analysis
}

\begin{abstract}
Two-dimensional partitioning of variation was used to determine the sources of relationships between the yield and vegetative characteristics of three 'Cabernet Sauvignon' grape (Vitis vinifera $\mathbf{L}$.) clones. Clonal differences were found in shoot growth rate, but not in duration or total growth. A weak positive relationship between total shoot growth and yield resulted from a positive relationship between fruit set and growth duration. Relationships between cluster number and foliar characteristics indicated that light exposure in the previous year may have influenced both vegetative and reproductive development. The mean number of clusters per bud was positively related to the mean area, dry weight, and nitrogen content of leaves.
\end{abstract}

In viticulture, a balance between grapevine vegetative growth and crop load is considered essential for the consistent production of high yields of quality fruit (Winkler et al., 1974). To achieve such a balance in any vineyard, an understanding of the

Received for publication 15 Mar. 1989. Supported in part by the Natural Sciences and Engineering Research Council of Canada through a fellowship to P.A.B. We thank R.M. Carlson for technical advice on leaf nitrogen analysis. The cost of publishing this paper was defrayed in part by the payment of page charges. Under postal regulations, this paper therefore must be hereby marked advertisement solely to indicate this fact.

'Present address: Agriculture Canada Research Station, Agassiz, B.C. V0M 1A0, Canada. conditions that control both growth and productivity is needed so that effective adjustments can be made culturally.

Over a growing season, the development of a grapevine is controlled by two main factors: 1) initial pregrowth conditions of the vine, including its size, characteristics of its buds, and the amount of stored reserves; and 2) environmental conditions that regulate and modify shoot and fruit development. Early season growth is determined mainly by the sharing of stored reserves among all shoots developing on a vine (Winkler et al., 1974). As the season progresses, the dependence of each shoot upon stored reserves decreases as its own photosynthetic output increases (Hale and Weaver, 1962; Kliewer, 1981). Each shoot 
is thus increasingly influenced by environmental conditions that determine photosynthetic performance.

Of the various climatic components that affect the photosynthesis and development of grapevine shoots, solar radiation is most significantly attenuated by the canopy (Smart, 1985). Thus, patterns of shoot growth and development within a vineyard exhibit strong relationships with light microclimate. Well-exposed shoots-generally have shorter internodes, thicker diameters, and greater total dry weights than shaded shoots (Buttrose, 1969; Kliewer et al., 1972; May, 1960; Morgan et al., 1985). Leaves developing under high light are generally thicker and have lower specific leaf areas, higher $\mathrm{N}$ contents, and greater photosynthetic capacities than shade leaves (Buttrose, 1968; Kliewer et al., 1972; Kriedemann, 1968; Morgan et al., 1985; Williams, 1987). Relationships between shoot vegetative characteristics and fruit productivity may thus reflect differences in light exposure and the ability of leaves to supply assimilates to developing clusters.

From the onset of bud development, vegetative and reproductive components of shoots develop simultaneously and depend on a common resource pool. Positive correlations between the growth rate and productivity of shoots may thus reflect variation in overall resource availability. However, there is evidence that, at particular stages of shoot and fruit cluster development, differences between the sink strengths of growing shoot tips and developing clusters can lead to negative correlations between growth and yield (May, 1965; Pool, 1982; Winkler et al., 1974). During the bloom-fruit-set period, for example, clusters are weak sinks compared to shoot tips and conditions favoring rapid shoot growth often result in poor set (Coombe, 1962; Pool, 1982). At veraison and during fruit ripening, when clusters are strong sinks, shoot growth often declines in direct relation to crop load (Winkler et al., 1974).

This study investigated the developmental sources of relationships between shoot growth patterns, foliar characteristics, and fruit productivity in three 'Cabernet Sauvignon' clones. A statistical procedure, known as two-dimensional partitioning (TDP) (Eaton et al., 1986), was used to analyze the relationships and determine the developmental stages involved.

\section{Materials and Methods}

Yield development. The yield component model used was constructed for analysis in a preceding study (Bowen and Kliewer, 1990):

$$
\frac{\text { Clisters }}{\text { shoot }} \times \frac{\text { Flowers }}{\text { cluster }} \times \frac{\text { Berries }}{\text { flower }} \times \frac{\text { Seeds }}{\text { berry }} \times \frac{\text { Berry wt }}{\text { seed }}=\frac{\text { Yield }}{\text { shoot }}
$$

Yield component data were collected from 16 shoots of each of three 'Cabernet Sauvignon' clones known to differ in productivity (Bowen and Kliewer, 1990). Each shoot was located on a different vine, where it was randomly selected from one of four canes. Details of the vineyard site and data collection methods are in Bowen and Kliewer (1990).

Vegetative growth. Shoot development was monitored through the growing season by measuring the lamina lengths of all expanding primary leaves every 3 days from budbreak until harvest. At each time, the plastochron index (PI) (Erickson and Michelini, 1957) was calculated as the number of leaves exceeding a lamina reference length of $3 \mathrm{~cm}$. Plots of PI vs. time were used to observe the pattern of leaf initiation rate (LIR), and information derived was used to construct the following shoot growth model:
Leaf initiation rate $\times$ Growth duration $=$ Total leaf number.

The LIR for each shoot was calculated as the coefficient from a regression of PI upon time during the period of constant growth. Growth duration (GD) was then calculated as the number of days required to achieve the total number of leaves at harvest.

Two TDP analyses were conducted according to the procedure of Bowen (1987). The first analysis determined the clonal differences in GD and LIR and their contributions to total shoot growth. The second analysis determined the growth and yield component sources of relationships between the total growth and productivity of the shoots.

Foliar characteristics. At solar noon, 4 days before harvest, photosynthetic irradiance was measured with a LI-COR point quantum sensor (LI-190 SB, LI-COR, Lincoln, Neb.) at the canopy surface and under four successive leaf layers of two randomly selected vines of each clone. Light" measurements were made at the canopy shoulder, i.e., the point at which the shoots arched and began growing downward. Experience has shown that leaf exposure in this part of grapevine canopies is relatively constant through most of the growing season. Two leaf discs, $1.8 \mathrm{~cm}$ in diameter, were sampled (Fig. 1) from a leaf at the position where each light measurement was taken. Each pair of leaf discs was dried and weighed individually. A modified Kjedlahl procedure (Carlson, 1978) was used to analyze the total $\mathrm{N}$ content of each disc pair, except those collected from the fourth leaf layer, since they weighed less than the 20-mg minimum required for the $\mathrm{N}$ analysis.

Two days before harvest, two leaf discs were sampled, as in Fig. 1, from each leaf on the individual bearing shoots. Each disc pair was individually dried and weighed and the dry weight per area $\left(\mathrm{W}_{\mathrm{A}}\right)$ was taken as representative of the whole leaf. Samples of two disc pairs weighing the lowest, highest, and about average for each shoot were analyzed for N. Since the N concentration $\left(\mathrm{N}_{\mathrm{w}}\right)$ of the three samples was fairly constant for each shoot, and unrelated to $\mathrm{W}_{\mathrm{A}}$, their mean was used to estimate the $\mathrm{N}$ concentration per area $\left(\mathrm{N}_{\mathrm{A}}\right)$ of each leaf on the shoot as the product of $\mathrm{W}_{\mathrm{A}}$ and mean $\mathrm{N}_{\mathrm{A}}$.

The area (A) of each leaf on the shoots was estimated from the square of its lamina length using a regression equation calculated from 25 sampled leaves of various sizes from the ex-

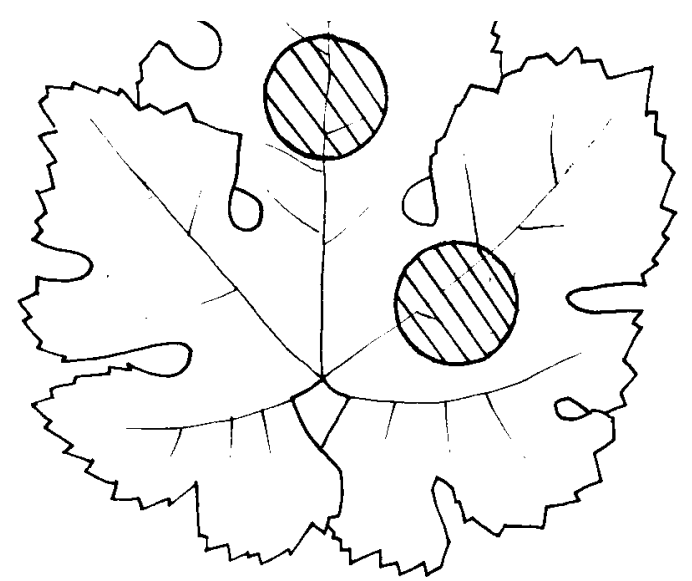

Fig. 1. 'Cabernet Sauvignon' leaf showing locations where leaf discs were sampled. 
perimental vines $\left(R^{2}=0.99\right)$. The total dry weight $\left(\mathrm{W}_{\mathrm{T}}\right)$ and nitrogen content $\left(\mathrm{N}_{\mathrm{T}}\right)$ of each leaf were estimated as products of $A$ and $W_{A}$, and $A$ and $N_{A}$, respectively. Shoot means and totals for $A, W_{A}, W_{T}, N_{A}$, and $N_{T}$ were calculated using all leaves and the 10 basal leaves only.

Relationships between shoot productivity and foliar characteristic means and totals were determined by regression analysis. Yield components responsible for significant relationships were determined by TDP analysis (Bowen, 1987).

Bud fruitfulness. Once dormant, each shoot (now a cane) was pruned to 15 nodes. During bud, burst in the following spring, cluster counts were made on all emerging primary shoots as soon as they appeared. Each shoot was removed after its clusters were counted to promote the development of remaining unburst buds. Cluster counts, were thus obtained for $86 \%$ of all primary buds.

\section{Results and Discussion}

During the period of rapid shoot growth (between 10 and 80 days after budbreak), LIR was constant for a given shoot, but varied among shoots (Fig. 2). Most shoots exhibited a sudden slowing and cessation of growth during veraison, which is normal for most grapevines (Winkler et al., 1974), but several shoots continued growing at a fairly constant rate through veraison and up until harvest (Fig. 2). The tendency for some 'Cabernet Sauvignon' shoots to grow vegetatively throughout the season may be explained by the dry matter allocation model of Gutierrez et al. (1985). They showed that 'Cabernet Sauvignon', unlike many other cultivars, allocates large amounts of dry matter to stem growth at the expense of crop. However, shoot growth after veraison is also known to be influenced by the water and $\mathrm{N}$ status of the soil, as well as by crop load (Winkler et al., 1974).

Across clones, LIR and GD were both significant determinants of final leaf number, contributing $25 \%$ to $75 \%$, respectively (Table 1). Significant clonal variation in LIR (Table 1)

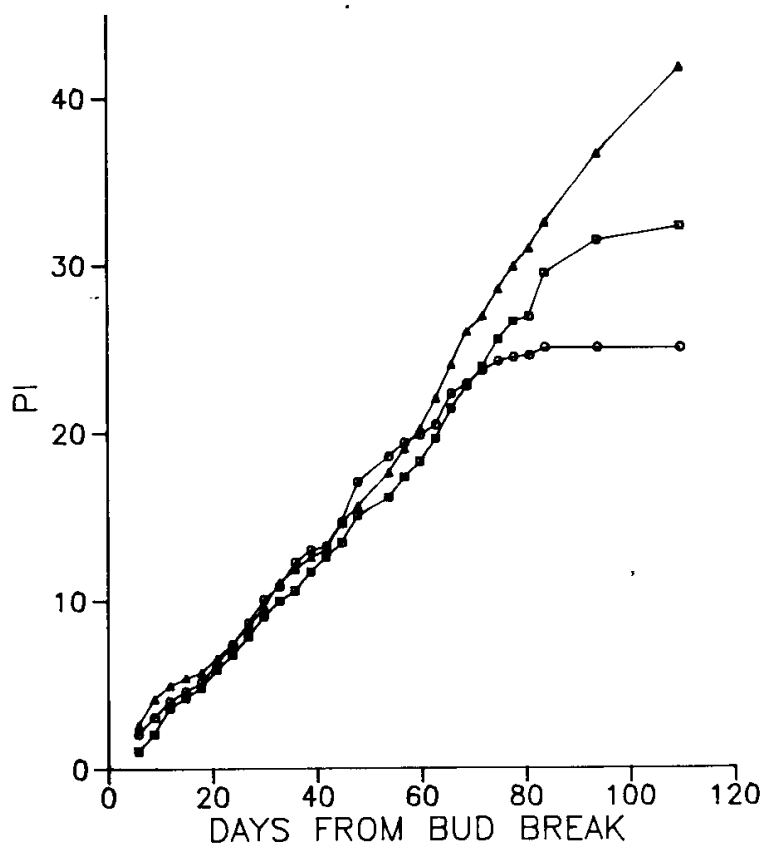

Fig. 2. Plastochron index (PI) vs. time (days from budbreak) for three shoots, showing differences in both the rate and duration of growth. Veraison occurred $\approx 90$ days after budbreak. resulted from a greater LIR exhibited by the low-yielding clone ( 0.45 leaf/day vs. 0.40 leaf/day for both the moderate and highyielding clones, untabulated). Both GD and total leaf number per shoot did not differ among clones (Table 1). The negative interaction between clone, GD, and LIR (Table 1) indicates that GD compensated for the clonal differences in LIR, i.e., the faster-growing shoots of the low-yielding clone tended to grow for a shorter duration. GD was so variable within clones that differences among clones were nonsignificant.

In a preceding study of the same shoots (Bowen and Kliewer, 1990), results indicated that inadequate resource partitioning to developing clusters led to the poor productivity of the lowyielding clone. The faster shoot growth rate of the low-yielding clone indicates that assimilate partitioning favored vegetative growth more in this clone than in the two higher-yielding clones (Table 1).

There was a weak positive relationship between yield and the number of leaves per shoot at harvest (Fig. 3, Table 2). This trend resulted mainly from a positive relationship between berries/flower (fruit set) and GD (Table 2). Since fruit set occurred long before any shoot completed its growth, it is unlikely that the relationship resulted from a discrete event or an agent acting at a single developmental stage. Light exposure was unlikely the limiting factor because all shoots were well-exposed during fruit set. One possibility is that a nutrient supplied continuously from outside the shoot, such as $\mathrm{N}$, limited both fruit set and GD.

The strong negative relationship found between flowers/clus-

Table 1. Two-dimensional partitioning of shoot growth variation among clonal sources. Contributions to total variation in leaf number expressed as $R^{2}$ percentages.

\begin{tabular}{|c|c|c|c|c|}
\hline \multirow[b]{2}{*}{ Source } & \multicolumn{2}{|c|}{ Growth components } & \multirow[b]{2}{*}{ Interactions } & \multirow[b]{2}{*}{$\begin{array}{c}\text { Total } \\
\text { leaf } \\
\text { number }\end{array}$} \\
\hline & $\begin{array}{l}\text { Leaf } \\
\text { initiation } \\
\text { rate }\end{array}$ & $\begin{array}{c}\text { Growth } \\
\text { duration }\end{array}$ & & \\
\hline Clones & $3^{*}$ & 4 & -7 & 0 \\
\hline Residual & 22 & 71 & 7 & 100 \\
\hline Total & $25^{* *}$ & $75^{* *}$ & & 100 \\
\hline
\end{tabular}

*,**Significant at $P=0.05$ or 0.01 , respectively.

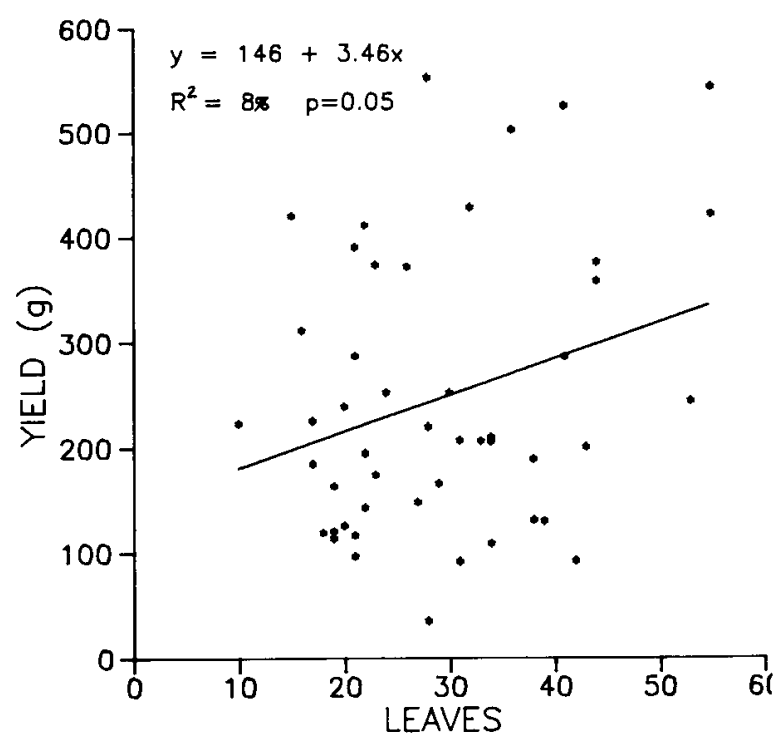

Fig. 3. Relationship between yield and total leaf number at harvest for individual shoots. 
Table 2. Two-dimensional partitioning of yield-per-shoot variation among vegetative growth component sources. Contributions to total yield variation expressed as $R^{2}$ percentages.

\begin{tabular}{|c|c|c|c|c|c|c|c|}
\hline \multirow[b]{2}{*}{ Source } & \multicolumn{5}{|c|}{ Yield components } & \multirow[b]{2}{*}{ Interactions } & \multirow[b]{2}{*}{$\begin{array}{l}\text { Yield/ } \\
\text { shoot }\end{array}$} \\
\hline & $\begin{array}{l}\text { Clusters/ } \\
\text { shoot }\end{array}$ & $\begin{array}{l}\text { Flowers/ } \\
\text { cluster }^{2}\end{array}$ & $\begin{array}{l}\text { Berries/ } \\
\text { flower }\end{array}$ & $\begin{array}{l}\text { Seeds/ } \\
\text { berry }\end{array}$ & $\begin{array}{c}\text { Berry wt/ } \\
\text { seed }\end{array}$ & & \\
\hline Leaf initiation rate & 0 & $0.02^{* * y}$ & 2 & 0 & 0 & -1 & 1 \\
\hline Growth duration & 0 & 0.00 & $10^{*}$ & 0 & 0 & -4 & $6^{*}$ \\
\hline Residual & 31 & 0.08 & 50 & 4 & 3 & 5 & 93 \\
\hline Total & $31^{* *}$ & 0.10 & $62^{* *}$ & 4 & 3 & & 100 \\
\hline
\end{tabular}

${ }^{2} R^{2}$ values in the column for flowers/cluster have been rounded to the nearest $0.01 \%$, rather than to the nearest $1 \%$, to show the portion of variation contributed by leaf initiation rate.

y The regression coefficient was negative.

${ }^{*, * *}$ Significant at $P=0.05$ or 0.01 , respectively.

ter and LIR (Table 2) suggests that rapid shoot growth early in the season competed with cluster development, especially the resumption and completion of flower development from existing primordia. However, little yield variation was contributed by flowers/cluster $\left(R^{2}=0.1 \%\right.$, Table 2$)$, so the negative effect of rapid shoot growth on final yield was also small $\left(R_{2}=0.02 \%\right.$, Table 2).

Relationships of $\mathrm{W}_{\mathrm{A}}$ and $\mathrm{N}_{\mathrm{A}}$ with the mean light intensity measured at successive leaf layers were logarithmic (Figs. 4 and 5 ) and did not differ among clones or vines within clones. Variation in light microclimate was thus responsible for much of the variation in leaf $\mathrm{W}_{\mathrm{A}}$ and $\mathrm{N}_{\mathrm{A}}$. These results are consistent with those found for other woody perennial fruit crops (DeJong and Doyle, 1985; Marini and Marini, 1983; Porpiglia and Barden, 1980; Syvertsen and Smith, 1984). In a study with peaches, $\mathrm{N}_{\mathrm{A}}$ was found to correlate positively with photosynthetic capacity, presumably because of a greater incorporation of nitrogen into leaf cellular proteins such as ribulose bisphosphate carboxylase under high light (DeJong and Doyle, 1985). Since the photosynthetic capacity of grape leaves is influenced by light environment (Kriedemann, 1968), our results may indicate that $\mathrm{N}$ is allocated preferentially to the more exposed leaves of a grapevine, which will optimize whole-vine photosynthesis.

Differential partitioning of $\mathrm{N}$ through the canopy profile of

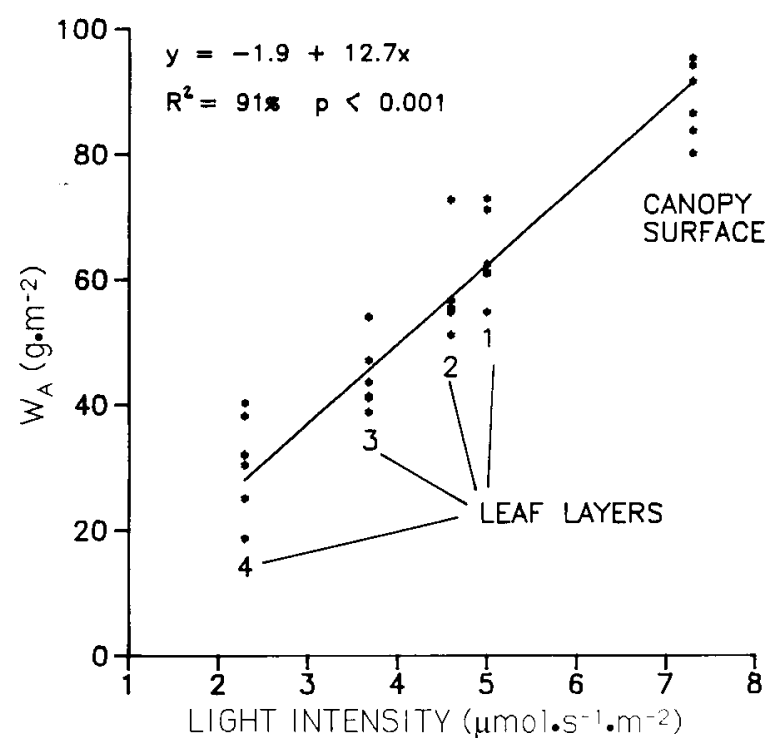

Fig. 4. Relationship between leaf dry weight per area $\left(W_{A}\right)$ and the log of the mean light intensity (PPF) measured at successive leaf layers in the canopies of six vines.

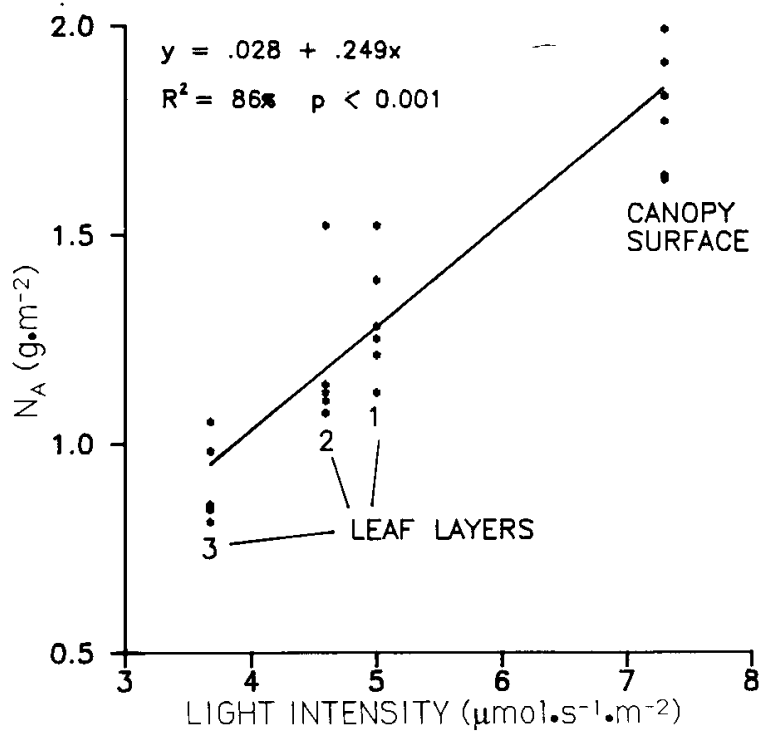

Fig. 5. Relationship between leaf $\mathrm{N}$ content per area $\left(\mathrm{N}_{\mathrm{A}}\right)$ and the log of the mean light intensity (PPF) measured at successive leaf layers in the canopies of six vines.

grapevines was also reported by Williams (1987), who found a decrease in $\mathrm{N}_{\mathrm{w}}$ from the canopy surface to the interior in 'Thompson Seedless'. In this study, no relationship was found between $\mathrm{N}_{\mathrm{w}}$ and light intensity measured at successive leaf layers, which is consistent with data obtained from other woody perennials (Erez and Weinbaum, 1985; Weinbaum et al., 1989).

Relationships between yield and foliar characteristics were positive, but generally weak (Table 3 ). The strongest was between yield and the mean $\mathrm{W}_{\mathrm{T}}$ of the first 10 leaves (Fig. 6). The single yield component source of this relationship was cluster number, and there were positive interactions between $\mathrm{W}_{\mathrm{T}}$, cluster number, and later-developing yield components (Table 4). Similar TDP results were found for all other foliar characteristics related to yield (listed in Table 3). Several previous findings suggest that relationships between foliar characteristics and cluster number can result from variation in cane light exposure in the previous year. In studies showing a positive effect of light exposure on the development of cluster primordia in grape buds, correlations between the sizes of cluster and leaf primordia were also found (Buttrose, 1970; May, 1965). Normally, shoots that develop under well-exposed conditions not only have more fruitful buds (Hopping, 1977), but store greater amounts of nutrient reserves to support early growth in the following year (Kliewer et al., 1972; Scholefield et al., 1977). 
Table 3. Coefficients of determination $\left(R^{2}\right)$ and significance of linear regressions of yield per shoot upon shoot vegetative characteristics. ${ }^{2}$

\begin{tabular}{lc}
\hline \hline Characteristic & $R^{2}(\%)$ \\
\hline Diameter at base & $14^{* *}$ \\
Internode length & $2^{\text {Ns }}$ \\
Leaf number & $8^{*}$ \\
Total leaf area & $10^{*}$ \\
Total leaf dry weight & $14^{* *}$ \\
Total leaf nitrogen & $13^{* *}$ \\
Mean per leaf.(all leaves) & \\
Area & $3^{\mathrm{Ns}}$ \\
Dry weight & $15^{* *}$ \\
Dry weight/area & $6^{\mathrm{NS}}$ \\
Nitrogen & $15^{* *}$ \\
Nitrogen/area & $6^{\mathrm{NS}}$ \\
Mean per leaf (first 10 leaves) & \\
Area & $6^{\mathrm{Ns}}$ \\
Dry weight & $20^{* *}$ \\
Dry weight/area & $16^{* *}$ \\
Nitrogen & $18^{* *}$ \\
Nitrogen/area & $17^{* *}$ \\
\hline
\end{tabular}

${ }^{\mathrm{z}}$ All regression coefficients were positive.

Ns, *,**Regressions not significant or significant at $P=0.05$ or 0.01 , respectively.

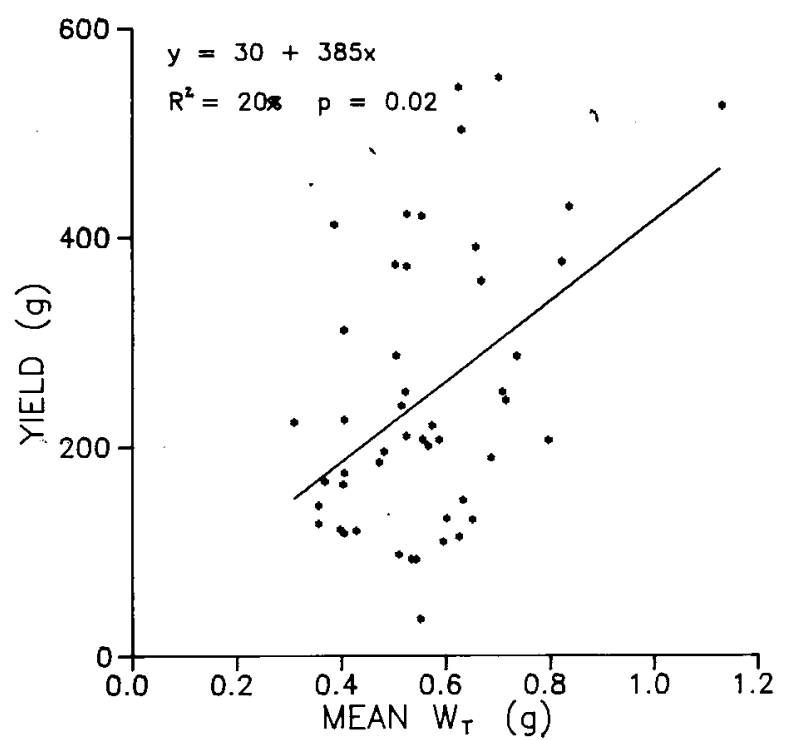

Fig. 6. Relationship between yield and the mean dry weight $\left(\mathrm{W}_{\mathrm{T}}\right)$ of the 10 basal leaves of individual shoots.

Thus, shoots developing on exposed canes are generally more fruitful and exhibit better vegetative growth than shoots on shaded canes (Kliewer, 1981).

Further evidence that light exposure in the previous year limited both leaf and cluster development is provided by the strengths of the relationships between yield and foliar characteristics on different portions of the shoots (Table 3). Mean leaf area, dry weight, and $\mathrm{N}$ content calculated from the 10 basal leaves exhibited closer relationships with yield than those calculated from the entire shoot (Table 3). Since the 10 basal leaves develop from primoridal leaves (Buttrose, 1969) and depend on stored reserves for their initial development, they are most influenced by environmental conditions, such as light exposure, that affect storage and bud development in the previous year.

The positive interactions between leaf characteristics, cluster number, and later-developing yield components (see those listed
Table 4. Two-dimensional partitioning of yield per shoot variation between the mean dry weight of the first 10 leaves and residual sources. Contributions to total yield variation expressed as $R^{2}$ percentages.

\begin{tabular}{|c|c|c|c|c|c|c|c|}
\hline \multirow[b]{2}{*}{ Source } & \multicolumn{5}{|c|}{ Yield components } & \multirow[b]{2}{*}{$\begin{array}{l}\text { Inter- } \\
\text { actions }\end{array}$} & \multirow[b]{2}{*}{$\begin{array}{l}\text { Yield/ } \\
\text { shoot }\end{array}$} \\
\hline & $\begin{array}{c}\text { Clusters/ } \\
\text { shoot }\end{array}$ & $\begin{array}{c}\text { Flowers/ } \\
\text { cluster }\end{array}$ & $\begin{array}{l}\text { Berries/ } \\
\text { flower }\end{array}$ & $\begin{array}{c}\text { Seeds/ } \\
\text { berry }\end{array}$ & $\begin{array}{c}\text { Berry } \\
\text { wt/ } \\
\text { seed }\end{array}$ & & \\
\hline Dry weight & $4 * *$ & 0 & 2 & 0 & 0 & 8 & $14^{* *}$ \\
\hline Residual & 27 & 0 & 60 & 4 & 3 & -8 & 86 \\
\hline Total & $31^{* *}$ & 0 & $62^{* *}$ & 4 & 3 & & 100 \\
\hline \multicolumn{4}{|c|}{ Interaction } & & $R^{2}$ & & \\
\hline \multicolumn{5}{|c|}{ Leaf dry wt $\times$ clusters/shoot $\times$ berries/flower } & 4 & & \\
\hline \multicolumn{5}{|c|}{ Leaf dry wt $\times$ clusters $/$ shoot $\times$ seeds $/$ berry } & 2 & & \\
\hline Leaf dry wt & $\times$ cluster & s/shoot & $x$ berry & $\mathrm{vt} /$ seed & 2 & & \\
\hline
\end{tabular}

** Significant at $P=0.01$.

Table 5. Coefficients of determination $\left(R^{2}\right)$ from linear regressions of the mean number of clusters per primary bud upon primary leaf characteristics of the first 15 nodes. ${ }^{z}$

\begin{tabular}{lc}
\hline \hline Characteristic & $R^{2}(\%)$ \\
\hline Mean per leaf & \\
Area & 27 \\
Dry weight & 45 \\
Dry weight/area & 19 \\
Nitrogen & 44 \\
Nitrogen/area & 30 \\
\hline${ }^{2}$ All regression coefficients were positive and significant at $P=0.01$.
\end{tabular}

at the bottom of Table 4) indicate that shoots bearing more clusters exhibited better set and developed larger berries if they had high leaf dry weights or $\mathrm{N}$ contents. This suggests that light exposure and photosynthetic capacity of leaves limited set and berry development on high-cropping shoots. Other studies have found reductions in fruit set and berry development on shoots exposed to low light (Kliewer and Antcliff, 1970; May and Antcliff, 1963; Morgan et al., 1985). In one study, the reduction in berry enlargement under low light was associated with decrease in $\mathrm{W}_{\mathrm{A}}$ (Morgan et al., 1985).

The mean number of clusters per primary bud at the first 15 nodes was positively related to several foliar characteristics (Table 5), the strongest being with mean $\mathrm{W}_{\mathrm{T}}($ Fig. 7). These relationships, especially those with $\mathrm{W}_{\mathrm{A}}$ and $\mathrm{N}_{\mathrm{A}}$, may reflect the influence of light environment on both fruit-bud induction (Buttrose, 1970; May, 1965; May and Antcliff, 1963) and leaf characteristics (Figs. 4 and 5). Because shoot light exposure was not measured directly in this study, the extent to which light exposure determined bud fruitfulness is unknown.

With the exception of mean A, foliar characteristics related to the number of clusters per bud were also related to the number of clusters carried by the shoots. Our results indicated that the light environment of developing canes in the previous year may have influenced these foliar characteristics, especially at the basal portion of the shoot. It is possible, therefore, that cane light exposure in the previous year indirectly affected fruit-bud induction in the current year by influencing foliar development 


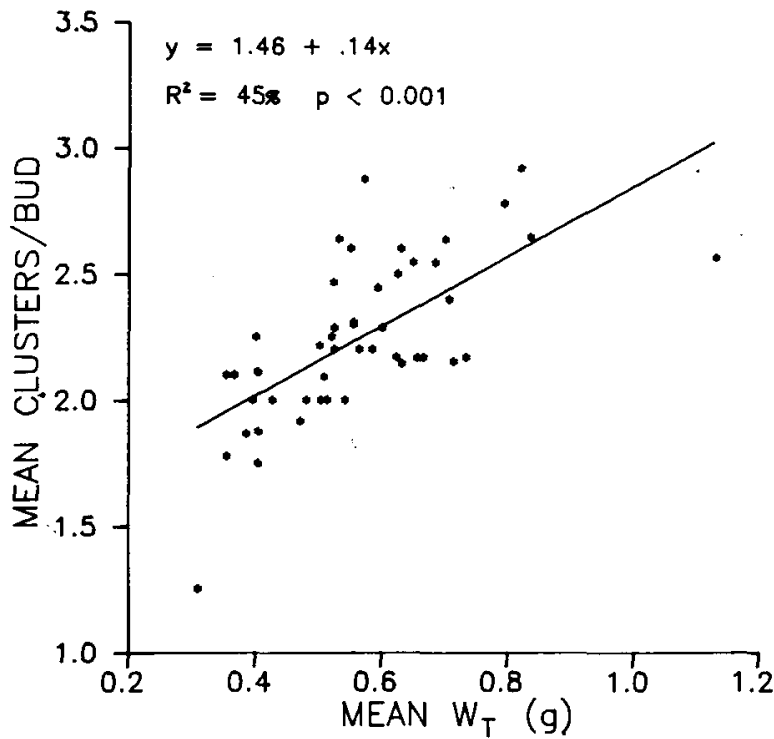

Fig. 7. Relationship between the mean number of clusters per primary bud and the mean leaf dry weight $\left(\mathrm{W}_{\mathrm{T}}\right)$ for the 15 basal nodes of individual shoots.

and photosynthetic capacity. This implies a 2-year carryover effect of light microclimate on shoot fruitfulness. Further research is needed to determine the full effect of cane light exposure on leaf and bud development in the following year.

We found no evidence that competition for resources between the vegetative and reproductive components of shoots diminished either growth or yield. The weak positive relationship between total growth and productivity points to the importance of overall vine nutrition promoting both growth and yield development.

\section{Literature Cited}

Bowen, P.A. 1987. An analysis of sources of yield variation in three Cabernet Sauvignon clones. PhD Diss., Univ. of California, Davis. Bowen, P.A. and W.M. Kliewer. 1990. Influence of clonal variation, pruning severity, and cane structure on yield component development in 'Cabernet Sauvignon' grapevines. J. Amer. Soc. Hort. Sci. 115(4):530-534.

Buttrose, M.S. 1970. Fruitfulness in grapevines: Development of leaf primordia in buds in relation to bud fruitfulness. Bot. Gaz. 131:7883.

Buttrose, M.S. 1969. Vegetative growth of grapevine varieties under controlled temperature and light intensity. Vitis 8:280-285.

Buttrose, M.S. 1968. Some effects of light intensity and temperature on dry weight and shoot growth of grape-vine. Ann. Bot. 32:753765 .

Carlson, R.M. 1978. Automated separation and conductimetric determination of ammonia and dissolved carbon dioxide. Anal. Chem. 50:1528-1531.

Coombe, B.G. 1962. The effect of removing leaves, flowers and shoots tips on fruit set in Vitis vinifera L.J. Hort. Sci. 37:1-15.

DeJong T.M. and J.F. Doyle. 1985. Seasonal relationships between leaf nitrogen content (photosynthetic capacity) and leaf canopy light exposure in peach. Plant Cell Environ. 8:701-706.
Eaton, G.W., P.A. Bowen, and P.A. Jolliffe. 1986. Two-dimensional partitioning of yield variation. HortScience 21:1052-1053.

Erez, A. and S.A. Weinbaum. 1985. Field estimation of leaf nitrogen by light transmittance. J. Plant Nutr. 8:103-115.

Erickson, R.O. and F.J. Michelini. 1957. The plastochron index. Amer. J. Bot. 44:297-305.

Gutierrez, A.P., D.W. Williams, and H. Kido. 1985. A model of grape growth and development: The mathematical structure and biological considerations. Crop Sci. 25:721-728.

Hale, C.R. and R.J. Weaver. 1962. The effect of developmental stages on direction of translocation of photosynthate in Vitis vinifera. Hilgardia 33:39-131.

Hopping, M.E. 1977. Effect of light intensity during cane development on subsequent bud break and yield of Palomino grape vines. N.Z. J. Expt. Agr. 5:287-290.

Kliewer, W.M. 1981. Grapevine physiology: How does a grapevine make sugar? Univ. Calif. Coop. Ext. Serv. Lflt. 21231.

Kliewer, W.M. and A.J. Antcliff. 1970. Influence of defoliation, leaf darkening and cluster shading on the growth and composition of Sultana grapes. Amer. J. Enol. Viticult. 21:26-36.

Kliewer, W.M., L.A. Lider, and N. Ferrari. 1972. Effects of controlled temperature and light intensity on growth and carbohydrate levels of 'Thompson Seedless' grapevines. J. Amer. Soc. Hort. Sci. 97:185-188.

Kriedemann, P.E. 1968. Photosynthesis in vine leaves as a function of light intensity, temperature and leaf age. Vitis 7:213-220.

Marini, R.P. and M.C. Marini. 1983. Seasonal changes in specific leaf weight, net photosynthesis and chlorophyll content of peach leaves as affected by light penetration and canopy position. J. Amer. Soc. Hort. Sci. 108:609-613.

May, P. 1965. Reducing inflorescence formation by shading individual Sultana buds. Austral. J. Biol. Sci. 18:463-473.

May, P. 1960. Effect of direction of growth on Sultana canes. Nature (London) 185:394-395.

May, P. and A.J. Antcliff. 1963. The effect of shading on fruitfulness and yield in the Sultana. J. Hort. Sci. 38:85-94.

Morgan, D.C., C.J. Stanley, and I.J. Barrington. 1985. The effects of simulated daylight and shadelight on vegetative and reproductive growth in kiwifruit and grapevine. J. Hort. Sci. 60:473-484.

Pool, R.M. 1982. Effect of mepiquat chloride on the growth and yield of Concord grapevines. J. Amer. Soc. Hort. Sci. 107:376-380.

Porpiglia, P.J. and J.A. Barden. 1980. Seasonal trends in net photosynthetic potential, dark respiration and SLW of apple leaves as affected by canopy position. J. Amer. Soc. Hort. Sci. 105:920-923.

Scholefield, P.B., P. May, and T.F. Neales. 1977. Harvest pruning and trellising of 'Sultana' vines: II. Effects on early spring development. Scientia Hort. 7: 115-122.

Smart, R.E. 1985. Manipulation of grapevine canopy microclimate with implications for yield and quality. Amer. J. Enol. Viticult. 36:230-239.

Syvertsen, J.P. and M.L. Smith, Jr. 1984. Light acclimation in citrus leaves: I. Changes in physical characteristics, chlorophyll, and nitrogen content. J. Amer. Soc. Hort. Sci. 109:807-812.

Weinbaum, S.A., S.M. Southwick, K.A. Shackel, T.T. Muraoka, W. Krueger, and J.T. Yeager. 1989. Photosynthetic photon flux influences macroelement weight and leaf dry weight per unit of leaf area in prune tree canopies. J. Amer. Soc. Hort. Sci. 114:720-723.

Williams, L.E. 1987. Growth of 'Thompson Seedless' grapevines: II. Nitrogen distribution. J. Amer. Soc. Hort. Sci. 112:330-333.

Winkler, A.J., J.A. Cook, W.M. Kliewer, and L.A. Lider. 1974. General viticulture. Univ. of California Press, Berkeley. 